\title{
Æðaflækjur í heila - yfirlitsgrein
}

\author{
Ólafur Árni Sveinsson¹ læknir, Ingvar H. Ólafsson² læknir, Einar Már Valdimarsson³ læknir
}

\section{ÁGRIP}

Æðaflækjur í heila eru sjaldgæfar en geta valdið alvarlegum heilablæðingum, varanlegri fötlun og dauða. Auk pessa geta pær valdið staðbundnum taugaeinkennum, flogum og höfuðverk. Meðferð æðaflækja er vandasöm. Algengust er skurðaðgerð par sem leitast er við að loka nærandi slagæðum. Einnig er notast við prívíddarmiðaða (stereotactic) geislameðferð eða innanæðarlokun (endovascular embolization) í sama tilgangi. Velja parf rétta meðferð fyrir hvert tilfelli og oft parf að beita fleiru en einu meðferðarformi til að loka æðaflækjunni. Nýlegar rannsóknir benda til bess að ekki eigi að grípa til aðgerðar pegar æðaflækjur hafa ekki blætt. í pessari grein er veitt yfirlit yfir faraldsfræði, einkenni, greiningu og meðferð æðaflækja í heila.

Fyrirspurnir: Ólafur Sveinsson, olafur.sveinsson@karolinska.se

\section{Inngangur}

'Taugadeild Karolinska Sjúkrahússins

Stokkhólmi, 2heila- og taugaskurðdeild, taugalækningadeild Landspítala.

22. febrúar 2016 sampykkt til birtinga 8. júlí 2016

\section{Aðferð̄ir}

Í æðaflækjum hefur frumstæð tenging á milli slagæðakerfis og bláæðakerfis haldist frá fósturstigi. Ekkert háræðakerfi er til staðar í hreiðri (nidus) æðaflækjunnar. Hreiðrið er miðjan par sem nærandi slagæðar (feeding arteries) flækjunnar koma saman og tengjast bláæðum hennar. Æðaflækjur eru algengastar ofan hnykiltjalds (supratentorial) í heilanum og yfirleitt er um stakar breytingar að ræða. ${ }^{1,2,3}$

Alvarlegasta afleiðing æðaflækju í heila er heilablæðing. Flestar æðaflækjur bera merki fyrri smærri blæðinga á næmum myndrannsóknum, jafnvel pó að einkennagefandi blæðingar hafi ekki átt sér stað. Æðaflækjur geta einnig valdið staðbundnum taugaeinkennum, flogum og höfuðverk. ${ }^{1-3}$ Meðferð æðaflækja er vandasöm. Algengust er skurðaðgerð par sem leitast er við að loka nærandi slagæðum. Einnig er notast við prívíddarmiðaða (stereotactic) geislameðferð eða innanæðarlokun (endovascular embolization) í sama tilgangi. $^{1-3}$ Í pessari grein er yfirlit yfir faraldsfræði, einkenni, greiningu og meðferð æðaflækja í heila. Ekki verða ræddar aðrar æðamissmíðar eins og æðaflækjur í mænu eða æðahnoð (cavernous hemangioma).

Gerð var leit í PubMed gagnasafninu. Notuð voru leitarorðin „cerebral arteriovenous malformations" og "arteriovenous malformations of the brain". Alls fengust 20074 (10146, 9928 ) heimildir í peirri leit. Áhersla var lögð á greinar sem birst hafa eftir 1990, en í vissum tilvikum leiddi leitin í ljós mikilvægar eldri heimildir. Eingöngu voru lesin ágrip á ensku. Aðeins voru lesnar greinar úr virtum ritrýndum tímaritum í taugalækn- ingum, taugaskurðlækningum og myndrannsóknum. Ágrip af fundum eða veggspjöldum voru ekki skoðuð. Gerðar voru pær kröfur að tilfellaraðir yrðu að hafa fleiri en 50 sjúklinga til að koma til álita. Yfirlitsgreinar í virtum tímaritum voru einnig teknar til greina. Greinar voru valdar út frá mikilvægi og pýðingu fyrir ritun pessarar yfirlitsgreinar. Af ofantöldum fjölda heimilda voru 332 ágrip lesin. Á grunni peirra voru 64 greinar lesnar og af peim var efni úr 43 notað í pessa grein.

\section{Faraldsfræði}

Æðaflækjur í heila eru jafnalgengar hjá báðum kynjum. Par sem hluti einstaklinga er einkennalaus alla ævi er afar erfitt að segja til um algengi. Рað hefur verið áætlað um 0,01\%, sem pýðir að einn af hverjum 10.000 hafi æðaflækju. ${ }^{5,6}$ Nýgengi einkennagefandi æðaflækja hefur verið áætlað rúmlega eitt tilvik á hverja 100.000 íbúa á ári. ${ }^{4}$ Samkvæmt pví ættu um prír til fjórir að veikjast árlega hérlendis. Aukin notkun myndgreiningar á síðari árum veldur pví að fleiri greinast fyrir tilviljun. ${ }^{7}$ Meirihluti æðaflækja í heila eru stök tilvik (sporadic). Til eru ættlæg heilkenni eins og Osler-Weber-Rendu og Sturge-Weber heilkennin, par eru æðaflækjur oft til staðar í fleiri líffærum en heilanum. ${ }^{2}$

Athyglisvert er að algengi æðaflækja í samanburði við æðagúla virðist afar mismunandi eftir löndum og kynpáttum. Til að mynda eru æðagúlar fimmfalt algengari en æðaflækjur í Bandaríkjunum og 14 sinnum algengari í Bretlandi. Hlutfallið er jafnt í Katar, Sádi-Arabíu og Kína. Í Singapúr er pessu öfugt farið, par eru æðaflækjur fjórfalt algengari en æðagúlar. ${ }^{8}$ 


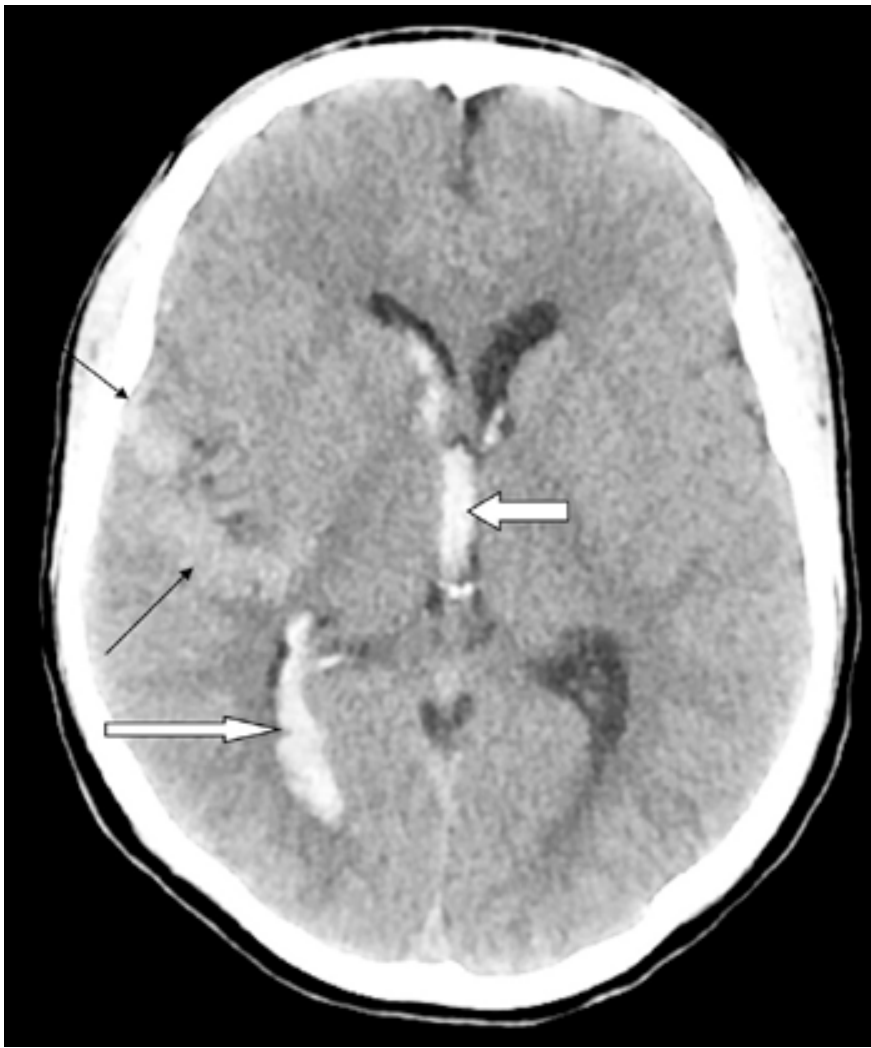

Mynd 1a. Tölvusneiðmynd sem sýnir blóð í hægra hliðarheilahólfi (löng ör) og priðja heilahólfi (stutt ör). Í hægra heilahveli sést hápéttnibreyting sem vekur grun um æðaflækju (grannar örvar).

\section{Klínísk einkenni}

Algengast er að sjúklingar með æðaflækju í heila leiti læknis vegna eftirfarandi: 1) heilavefsblæðingar, 2) floga, 3) staðbundinna taugaeinkenna, 4) höfuðverkjar og 5) blásturshljóðs í höfði (bruit).

\section{Heilavefsblæðing}

Heilavefsblæðing er algengasta upphafseinkennið (42-72\%), ásamt flogum. ${ }^{9,10}$ Blæðingarnar verða einkum á aldrinum 20 til 40 ára. ${ }^{9}$ pær valda um $2 \%$ af öllum heilablóðföllum. ${ }^{11,12}$ Heilavefsblæðingin er oftast staðbundin pó að blæðing inn í heilahólf eða innanskúmsblæðing komi fyrir. Einkennin ráðast af staðsetningu og umfangi blæðingarinnar. Brottfallseinkenni ásamt höfuðverk koma skyndilega eins og við aðrar tegundir heilavefsblæðinga.

Flog

Flog er fyrsta einkenni hjá $28-67 \%$ einstaklinga. Hjá helmingi peirra verður flogið innan við prítugt. Pessi hópur veikist að jafnaði fyrr en peir sem blæða. Athyglisvert er að flog eru tvöfalt algengari en blæðingar pegar æðaflækjur eru stórar

\section{Höfuðverkur}

Höfuðverkur vegna æðaflækju kemur fyrir hjá 5-35\% pessara einstaklinga. Verkurinn er yfirleitt ósértækur. Hann getur ver-

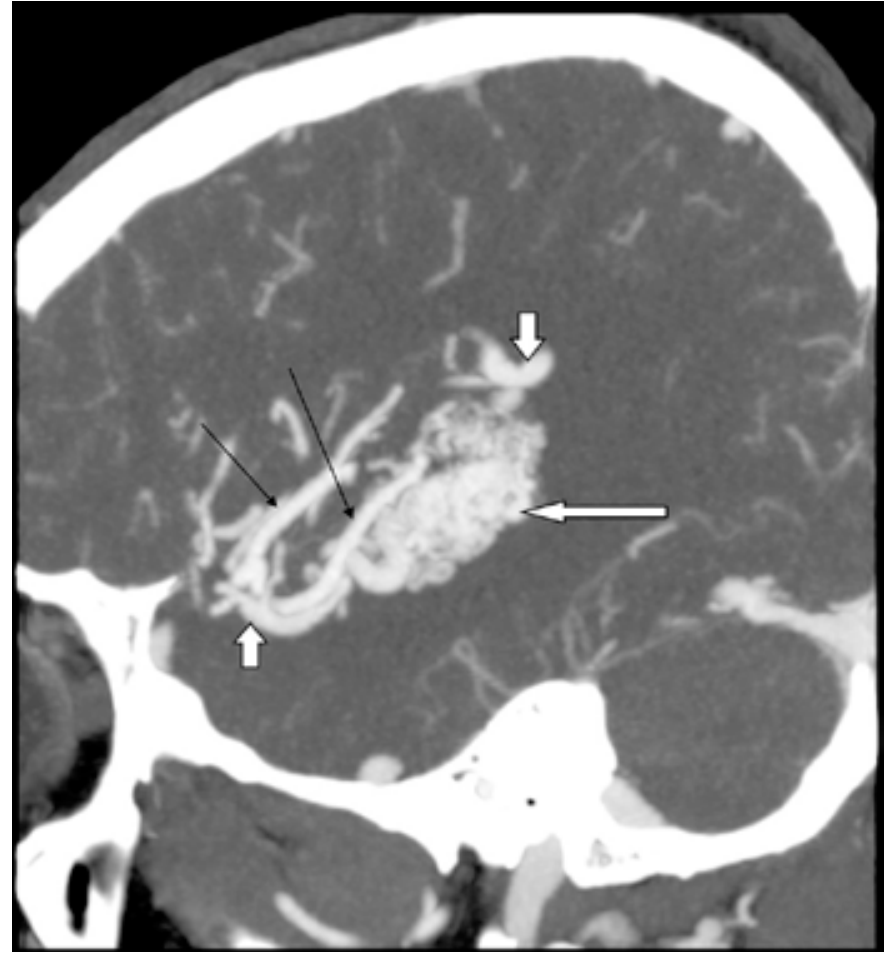

Mynd 1b. TS æðamynd sýnir æðaflækjuna með stóru hreiðri (nidus) $(3,5 \mathrm{~cm}$ í stærsta pvermál, löng hvít ör). Sjá má tvær nærandi slagæðar (grannar svartar örvar). Einnig má sjá tvær stórar fráflæðisbláæðar (stuttar hvítar örvar).

ið stöðugur, komið í köstum og verið öðrum megin eða báðum megin í höfðinu, og líkist gjarnan mígrenihöfuðverk. ${ }^{13}$

\section{Staðbundin taugaeinkenni}

Staðbundin taugaeinkenni eins og helftarlömun, máltruflun, skyneða sjónsviðsbrottfall koma fyrir. Einkenni ráðast af staðsetningu flækjunnar. Í æðaflækjunni par sem slagæðablóð á greiðan aðgang að bláæðakerfinu getur orðið blóðpurrð í aðliggjandi heilavef (cerebral steal syndrome). ${ }^{14}$ Blóðpurrðin getur leitt til einkenna skammvinnrar heilablóðpurrðar eða heiladreps. Einnig getur æðaflækjan með fyrirferð sinni valdið staðbundnum brottfallseinkennum.

\section{Blásturshliód}

Einstaklingar geta heyrt hljóð í höfði sem peir lýsa oft sem púlserandi í takt við æðasláttinn. Hljóðinu er lýst inni í höfðinu eða nær öðru hvoru eyranu. Slíkt getur verið vísbending um æðaflækju.

\section{Myndrannsóknir}

Hægt er að greina æðaflækjur með tölvusneiðmyndaæðarannsókn, segulómskoðun (SÓ) og SÓ-æðarannsókn og hefðbundinni æðamyndatöku (conventional catheter angiography) (mynd 1). Hefðbundin tölvusneiðmynd er næm til greiningar á bráðri heilablæðingu en varpar ekki fullnægjandi ljósi á æðaflækjuna sjálfa. Leggja verður áherslu á að hefðbundin tölvusneiðmynd útilokar ekki æðaflækju. Tölvusneiðmyndaæðarannsókn sýnir æðaflækjur með 


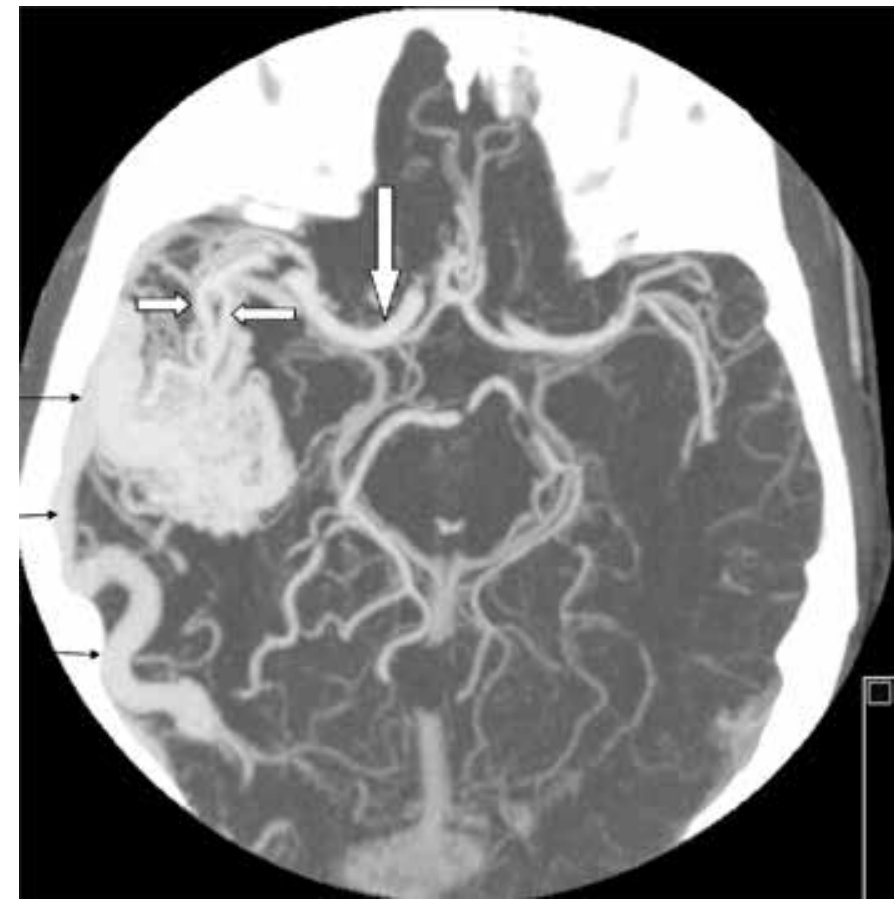

Mynd 1c. TS æðamynd sýnir að M1 æðin (löng hvít ör) er stærri en samsvarandi æð hinum megin. Einnig má sjá tvær M2 æðar sem næra æðaflækjuna (stuttar hvítar örvar). Pær eru stærri en samsvarandi æðar á hinni hliðinni. Einnig má sjá stóra fráflæðisbláæð (svartar örvar) sem liggur að pverstokki (sinus tranversus) á hægri hlið.

skýrum hætti og hefur yfirburði yfir segulómæðamynd. Segulómskoðunin gefur pó betri mynd af tengslum æðaflækju og aðlægs heilavefs. ${ }^{2}$ Hefðbundin æðamyndataka (conventional angiography) er kjörrannsókn pegar kemur að pví að gefa sem skarpasta mynd af uppbyggingu æðaflækjunnar, til að sýna fram á tilvist æðagúls og kortleggja bláæðafráflæðið. Æðaflækjur geta breyst og stækkað með tímanum. Peim breytingum má fylgja eftir með myndrannsóknum.

\section{Náttúrulegur gangur og horfur}

Stór krufningarannsókn gaf til kynna að eingöngu 12\% æðaflækja sýndu einkenni. ${ }^{15}$ Petta virðist vanmat pví að aðrar rannsóknir benda til pess að flestar æðaflækjur blæði að minnsta kosti einu sinni. ${ }^{5,16}$ Flestar rannsóknir mæla árlega grunnáhættu á blæðingu á bilinu 2-4\%. ${ }^{10,16-18}$ Blæðingunum fylgir 5-10\% dánartíðni og allt að helmingur hlýtur varanlega fötlun. ${ }^{5}$ Eftir að klínísk blæðing hefur átt sér stað er árleg áhætta talin hærri en grunnáhættan. Par eru tölur pó mjög á reiki, allt frá 4,5-34,4\%. ${ }^{10,16,19}$ Besta nálgunin telur um 6\% blæðingarlíkur á fyrsta árinu eftir blæðingu. Eftir fyrsta árið tekur grunnáhættan aftur við (2-4\%). ${ }^{17,20}$ Í framskyggnri rannsókn meðal 622 einstaklinga með æðaflækju sem fylgt var eftir að meðaltali í 2-3 ár var árleg hætta á blæðingu 5,9\% hjá peim sem höfðu blætt en 1,3\% meðal peirra sem ekki höfðu blætt. ${ }^{10}$

Ákveðnir pættir auka hættuna á blæðingu. Peir helstu eru: tilvist æðagúls, fráflæði inn í djúpa bláæðakerfið, djúp staðsetning æðaflækjunnar, til að mynda í djúphnoðum (basal ganglia), fjöldi fráflæðisbláæða og loks bláæðaprengsli. ${ }^{10,21}$

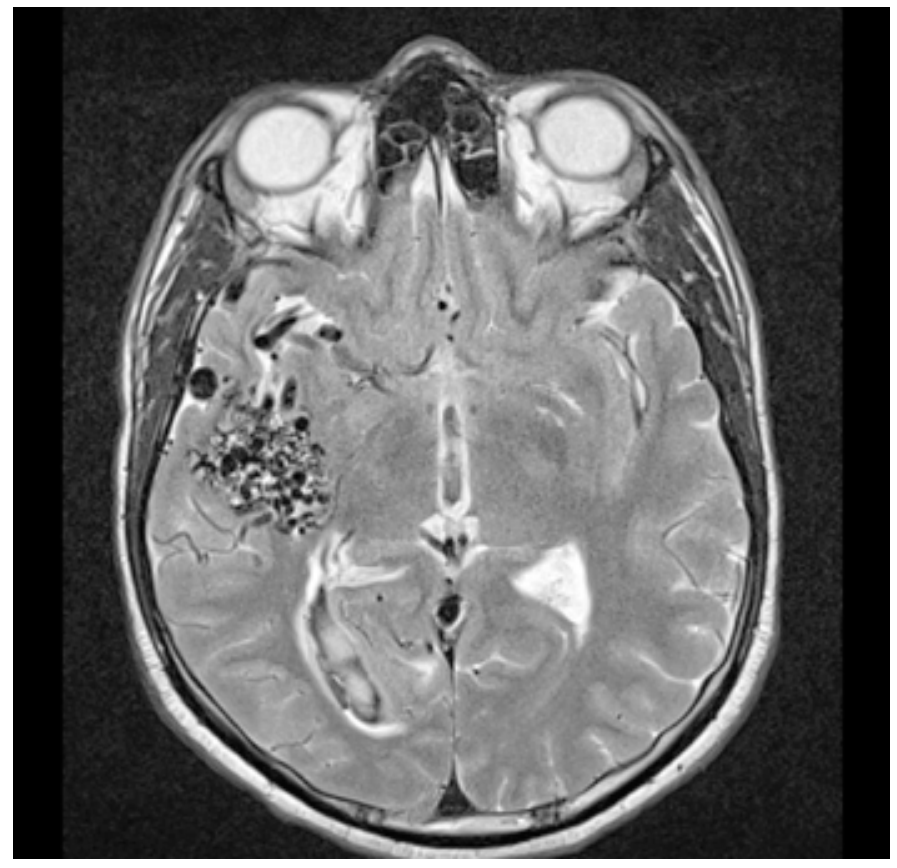

Mynd 1d. Segulómskoðun, T2 viktuð mynd, sýnir æðaflækjuna. Blóðið er svart inni í æðaflækjunni. Engin merki eru um bjúg á aðlægum svæðum. Einnig má sjá blóð í hægra heilahólfi, par er blóðið bæði svart og hvítt. Fer pað eftir aldri blóðsins.

Einnig fylgja ómeðhöndluðum æðaflækjum í hnakkagróf (posterior fossa) verri horfur. ${ }^{22}$ Sjúklingar með litlar æðaflækjur eru líklega í hlutfallslega meiri blæðingarhættu vegna pess að hjá peim er prýstingurinn í hreiðrinu (nidus) jafnan hærri. Hækkaður blóðprýstingur eykur einnig hættuna á blæðingu.

\section{Meðferð}

Áður fyrr var talið rétt að bjóða flestum einstaklingum með æðaflækju íhlutandi meðferð. Var pað fyrst og fremst vegna árlegrar blæðingaráhættu sem nefnd var að ofan. Landslagið í pessum efnum hefur breyst töluvert vegna svokallaðrar ARUBA (A Randomized Trial of Unruptured Brain Arteriovenous Malformations) rannsóknar sem birtist fyrir tæpum tveimur árum. Í peirri rannsókn var 223 manns með æðaflækju í heila sem ekki hafði blætt slembiraðað, annars vegar í hóp án inngrips og hins vegar í meðferðarhóp (skurðaðgerð, geislun eða innanæðarlokun). ${ }^{23}$ Eftir 33 mánaða eftirfylgd að meðaltali var dauði eða heilablóðfall marktækt algengara (31\%) í meðferðarhópnum en í hinum hópnum (10\%). Pví var frekari innskráning í rannsóknina stöðvuð. Fimm ára eftirfylgd hefur ekki breytt niðurstöðunni. Vissulega hafa ýmsir gagnrýnt aðferðafræði rannsóknarinnar en niðurstöðurnar munu líklega leiða til pess að meðferð einstaklinga með æðaflækju í heila verði íhaldssamari en áður. Ekki síst á pað við hjá peim einstaklingum sem ekki hafa blætt.

Pví verður í hverju tilviki að spyrja eftirfarandi spurninga: Eru líkur á pví að meðferðin valdi sjúklingi meiri skaða en sé hún ekki framkvæmd? Er hættan á blæðingu pað mikil að hún krefj- 
ist aðgerðar? Til að tryggja að sjúklingurinn fái bestu mögulegu meðferð er nauðsynlegt að teymi sérfræðinga taki slíka ákvörðun. Hafa ber í huga að skortur er á rannsóknum sem bera saman mismunandi meðferðarform (skurðaðgerð, prívíddarmiðuð geislameðferð og innanæðarlokun). Fleiri en ein meðferðartegund getur komið til greina hjá sama sjúklingi. Kostir einnar meðferðar geta vegið upp vankanta annarrar. ${ }^{24}$

Ef ákveðið er að meðhöndla er markmið meðferðarinnar full lokun æðaflækjunnar. Lokun að hluta er ekki talin leiða til minni blæðingaráhættu. Pó að höfuðmarkmið meðferðarinnar sé að fyrirbyggja blæðingu beinist meðferðin einnig að öðrum hugsanlegum afleiðingum flækjunnar, svo sem flogum og höfuðverk. ${ }^{24}$

Meta verður hvert tilfelli með tilliti til peirra pátta sem hafa áhrif á horfur og áhættu meðferðar. Ef blætt hefur frá lítilli æðaflækju sem situr á aðgengilegum stað og er ekki umvafin afar mikilvægum heilavef myndu líklega flestir vera sammála um að meðferðarinngrip sé æskilegt. Hins vegar er aðgerð ekki sjálfgefið úrræði ef æðaflækjan er stór, ef hún er staðsett á viðkvæmu svæði, nærð af mörgum slagæðum og hefur aldrei blætt.

Æðaflækjur í heila eru mjög mismunandi að uppbyggingu. bær geta nærst frá einni eða fleiri af stóru heilaslagæðunum. Petta á ekki síst við um stærri æðaflækjur sem liggja á mörkum næringarsvæða tveggja slagæða. Bláæðafráflæði æðaflækja getur einnig verið breytilegt. Рað getur tengst djúpa eða grunna bláæðakerfinu í heilanum eða tæmst beint inn í stóran bláæðastokk (sinus) eða haft alla ofannefnda farvegi. Áður en tekin er afstaða til meðferðar er nauðsynlegt að kortleggja flækjuna vel með æðamyndatöku.

\section{Skurðaðgerð}

Skurðaðgerð gegnir stóru hlutverki við meðferð æðaflækja. Ekkert meðferðarform er eins áhrifaríkt hvað varðar skjóta lokun flækjunnar. ${ }^{1}$ Í tilfelli 67 sjúklinga með æðaflækju sem var minni en $3 \mathrm{~cm}$ í pvermál tókst að loka flækjunni með skurðaðgerð í 94\% tilfella. ${ }^{25}$ Athyglisvert var að $45 \%$ æðaflækjanna voru á svæðum sem almennt teljast illa aðgengileg, eins og stúkan (thalamus), heilastofn og svæðið í kringum heilahólfin. Kosturinn við skurðaðgerð, ef hún tekst, er að æðaflækjunni er eytt. Skurðaðgerð er pó aldrei hættulaus.

Ákvörðun um skurðaðgerð ræðst af eftirfarandi páttum: stærð æðaflækjunnar, staðsetningu, fjölda nærandi slagæða, magni blóðflæðis í gegnum flækjuna, blóðpurrðareinkennum frá umlykjandi heilavef, mikilvægi aðliggjandi heilavefs og loks bláæðafrárennsli. Svokallaður Spetzler-Martin-skali hefur verið notaður til pess að meta áhættu skurðaðgerðar (sjá töflu I). ${ }^{26}$ Skalinn stigar
Tafla I. Skali Spetzler-Martin yfir skurðáhættu sjúklinga með æðaflækju. Fleiri stig, meiri áhætta.

\begin{tabular}{lc}
\hline Stærð (lengsta pvermál) & Stig \\
\hline $0-3 \mathrm{~cm}$ & 1 \\
\hline $3,1-6,0 \mathrm{~cm}$ & 2 \\
\hline$>6 \mathrm{~cm}$ & 3 \\
\hline Staðsetning & 0 \\
\hline Ekki á viðkvæmum stað & 1 \\
\hline Á viðkvæmum stað & \\
\hline Djúpt bláæðafráflæði & 0 \\
\hline Ekki til staðar & 1 \\
\hline Til staðar & \\
\hline
\end{tabular}

æðaflækjur út frá premur páttum sem hafa forspárgildi varðandi áhættu skurðaðgerðar: stærsta pvermál æðaflækjunnar, staðsetning (hvort flækjan er á viðkvæmum stað) og hvort fráflæði sé inn í djúpa bláæðakerfið. Bæði aftur- og framskyggnar rannsóknir hafa sýnt náið samband milli fjölda stiga og skurðáhættunnar. Oft er sjúklingum með stig I til III á Spetzler-Martin-skalanum boðin skurðaðgerð. Alvarlegir fylgikvillar við skurðaðgerð hjá peim hópi eru fátíðir. ${ }^{27,28}$ Við stig III er oft mælt með innanæðarlokun á undan skurðaðgerð. Skurðaðgerð fylgir mun hærri tíðni fylgikvilla ef stigin eru IV og V, pá er skurðaðgerð sjaldnast beitt. ${ }^{23,27,29}$

\section{Geislameðferð}

Gjarnan er mælt með geislameðferð ef æðaflækjan er minni en 3 cm í pvermál og er á viðkvæmum stað par sem skurðaðgerð gæti leitt til nýrra taugaeinkenna og fötlunar. Helsti ókostur geislameðferðar er biðtími, 1 til 3 ár, par til hámarkslokunaráhrif nást. Á biðtímanum er hætta á blæðingu. Líkur á fullri lokun eru minni en við skurðaðgerð..$^{30-32}$

Snemmkomnir fylgikvillar geislameðferðar geta verið flog, ógleði, uppköst, og höfuðverkur. Pessir fylgikvillar ganga flestir sjálfkrafa yfir. Í einni rannsókn fengu 5,2\% sjúklinga skammvinn taugaeinkenni en 1,4\% hlutu viðvarandi taugaeinkenni. ${ }^{30}$ Síðkomnir fylgikvillar (vikum og árum eftir meðferðina) eru flogaveiki, blæðing, geisladrep og bjúgur. Peim mun stærri sem æðaflækjan er, peim mun meiri hætta er á fylgikvillum og minni líkur á að full lokun náist. ${ }^{30,33}$ Hagstæðar niðurstöður hafa verið birtar fyrir stærri æðaflækjur með stigaðri (staged) geislameðferð. Pá er geisluninni beint á mismunandi svæði á mismunandi tímum með-

Tafla II. Samanburður á mismunandi meðferðarformum við æðaflækju í heila.

\begin{tabular}{|c|c|c|}
\hline Meðferðarform & Kostir & Ókostir \\
\hline Skurðaðgerð & $\begin{array}{c}\text { Áhrifarík eyðing æðaflækju og skjót minnkun } \\
\text { blæðingarhættu }\end{array}$ & Hætta á snemmkomnum taugaeinkennum \\
\hline Innanæðarlokun & $\begin{array}{c}\text { Minnkun æðaflækju fæst um leið og nærandi æðum } \\
\text { eða æðagúl er lokað. Stutt spítalavist }\end{array}$ & $\begin{array}{l}\text { Sjaldnast full lokun á æðaflækju. Viss hætta á nýjum } \\
\text { taugaeinkennum vegna blæðingar eða heilablóðpurrðar }\end{array}$ \\
\hline $\begin{array}{l}\text { Prívíddarmiðuð } \\
\text { geislameðferð }\end{array}$ & Ekki ífarandi inngrip. Stutt spítalavist & $\begin{array}{l}\text { 1-3 ára bið eftir fullum áhrifum á æðaflækju. Á meðan er } \\
\text { hætta á blæðingu. Hætta á síðkomnum geislaskaða }\end{array}$ \\
\hline
\end{tabular}


ferðarinnar. ${ }^{34}$ Í framskyggnri rannsókn á 500 sjúklingum (meðal eftirfylgdartími 7,8 ár) minnkaði hlutfallsleg hætta á blæðingu um $88 \% .^{30}$

Innanæðarlokun (embolization)

Pegar stærstu æðaflækjurnar eiga í hlut getur verið ráðlegt að beita svokallaðri innanæðarlokun áður en skurðaðgerð fer fram eða geislameðferð. Markmiðið með innanæðarlokuninni er að minnka blóðflæðið inn í flækjuna með pví að fækka nærandi slagæðum. î leiðinni má kortleggja æðaflækjuna fyrir skurðaðgerð. ${ }^{1}$ Páttur innanæðarlokunar í meðferð æðaflækja hefur farið vaxandi á undanförnum árum, ekki síst með bættum holleggjum (catheters) og betra efni til lokunar æðanna. ${ }^{35}$ Innanæðarlokun gerir eftirfylgjandi skurðaðgerð eða geislameðferð áhrifaríkari og hættuminni í meðferð flóknari og stærri æðaflækja. ${ }^{36,37}$ Rétt pykir að láta að minnsta kosti 4-6 vikur líða frá innanæðarlokun par til frekari meðferð er beitt. Styttri tími hefur verið tengdur aukinni blæðingarhættu.

Innanæðarlokun felur í sér lokun blóðflæðis til æðaflækjunnar með notkun innanæðarholleggja (intravascular catheters) par sem lagt er lokunarefni, til dæmis Onyx® í nærandi slagæðar og hreiður flækjunnar. Innanæðarlokun ein og sér dugar í undantekningatilvikum, nema flækjan sé undir $1 \mathrm{~cm}$ í pvermál og aðeins nærð af einni slagæð. ${ }^{38,39}$ Fylgikvillar verða í um 6-14\% tilfella. Flestir peirra eru minniháttar, pó geta stærri heilablæðingar og jafnvel andlát átt sér stað. ${ }^{39,40}$

\section{Meðferð æðagúla i tengslum við æðaflækju}

Æðagúlar eru til staðar hjá helmingi einstaklinga með æðaflækju. ${ }^{41}$ Ef æðagúllinn situr ekki á nærandi slagæð til æðaflækjunnar er hann meðhöndlaður eins og hver annar æðagúll. Sitji hann á nærandi slagæð er málið flóknara. Æðagúlar sem eru minni en 5 mm í pvermál og sitja á nærandi slagæð geta lokast pegar æðaflækjunni sjálfri er lokað. ${ }^{42}$ Ef æðagúllinn er yfir 5 mm í pvermál er honum oftast lokað áður en meðferð við æðaflækjunni er hafin. ${ }^{43}$

\section{Samantekt}

Æðaflækjur eru sjaldgæfar en geta valdið alvarlegum heilablæðingum, varanlegri fötlun og dauða. Auk pess geta pær orsakað flogaveiki. Töluverð próun hefur orðið síðastliðna áratugi í meðferð æðaflækja. Velja parf rétta meðferð fyrir hvert tilfelli og oft parf að beita fleiri en einni tegund meðferðar. Nýlegar rannsóknir gefa til kynna að engin íhlutandi meðferð sé besti kosturinn pegar æðaflækjur hafa ekki blætt. 


\section{Heimildir}

1. Gross BA, Rose D. Diagnosis and treatment of vascular malformations of the brain. Curr Treat Options Neurol 2014; $16: 279$.

2. Friedlander RM. Arteriovenous malformations of the brain. N Engl J Med 2007; 356:2704-12.

3. Ferrara AR. Brain arteriovenous malformations. Radiol Technol 2011; 82: 543-56.

4. Berman MF, Sciacca RR, Pile-Spellman J, Stapf C, Connolly ES Jr, Mohr JP, et al. The epidemiology of brain arteriovenous malformations. Neurosurgery 2000; 47: 38997.

5. ApSimon HT, Reef $\mathrm{H}$, Phadke RV, Popovic EA. A population-based study of brain arteriovenous malformation: long-term treatment outcomes. Stroke 2002; 33 2794-800.

6. Al-Shahi R, Fang JS, Lewis SC, Warlow CP. Prevalence of adults with brain arteriovenous malformations: a community based study in Scotland using capture-recapture analysis. J Neurol Neurosurg Psychiatry 2002; 73: 547-51.

7. Brown RD, Wiebers DO, Torner JC, O'Fallon WM Incidence and prevalence of intracranial vascular malformations in Olmsted County, Minnesota, 1965 to 1992. Neurology 1996; 46: 949-52.

8. Ohaegbulam SC. The epidemiology of brain arteriovenous malformations. Neurosurgery 2001; 49: 226-8.

9. Brown RD, Wiebers DO, Torner JC, O'Fallon WM Frequency of intracranial hemorrhage as a presenting symptom and subtype analysis: a population-based study of intracranial vascular malformations in Olmsted Country, Minnesota. J Neurosurg 1996; 85: 29-32.

10. Stapf C, Mast H, Sciacca RR, Choi JH, Khaw AV, Connolly ES, et al. Predictors of hemorrhage in patients with untreated brain arteriovenous malformation. Neurology 2006; 66: 1350-5.

11. Perret G, Nishioka H. Report on the cooperative study of intracranial aneurysms and subarachnoid hemorrhage. Arteriovenous malformations: an analysis of 545 cases of cranio-cerebral arteriovenous malformations and fistulae reported to the cooperative study. J Neurosurg 1966; 25 : $467-90$.

12. Gross CR, Kase CS, Mohr JP, Cunningham SC, Baker WE. Stroke in south Alabama: incidence and diagnostic features -- a population based study. Stroke 1984; 15: 249-55.

13. Monteiro JM, Rosas MJ, Correia AP, Vaz AR. Migraine and intracranial vascular malformations. Headache 1993; 33: 563-5

14. Taylor CL, Selman WR, Ratcheson RA. Steal affecting the central nervous system. Neurosurgery 2002; 50: 679-89.

15. McCormick WF. Classification, pathology, and natural history of angiomas of the central nervous system. Wkly Update Neurol Neurosurg 1978; 14: 2-7.

16. Ondra SL, Troupp H, George ED, Schwab K. The natura history of symptomatic arteriovenous malformations of the brain: a 24-year follow-up assessment. J Neurosurg 1990; 73: 387-91.

17. Graf CJ, Perret GE, Torner JC. Bleeding from cerebra arteriovenous malformations as part of their natural history. J Neurosurg 1983; 58: 331-7.

18. Brown RD, Wiebers DO, Forbes GS. Unruptured intracranial aneurysms and arteriovenous malformations: frequency of intracranial hemorrhage and relationship of lesions. J Neurosurg 1990; 73: 859-63.

19. Crawford PM, West CR, Chadwick DW, Shaw MD Arteriovenous malformations of the brain: natural history in unoperated patients. J Neurol Neurosurg Psychiatry 1986; 49: 1-10.

20. Wilkins RH. Natural history of intracranial vascular malformations: a review. Neurosurgery $1985 ; 16$ : 421-30.

21. Al-Shahi $R$, Warlow C. A systematic review of the frequency and prognosis of arteriovenous malformations of the brain in adults. Brain 2001; 124: 1900-26

22. Fleetwood IG, Marcellus ML, Levy RP, Marks MP, Steinberg GK. Deep arteriovenous malformations of the basal ganglia and thalamus: natural history. J Neurosurg 2003; 98: 747-50.

23. Mohr JP, Parides MK, Stapf C, Moquete E, Moy CS, Overbey JR, et al. Medical management with or withou interventional therapy for unruptured brain arteriovenous malformations (ARUBA): a multicentre, non-blinded, randomised trial. Lancet 2014; 383: 614-21.

24. Ogilvy CS, Stieg PE, Awad I, Brown RD Jr, Kondziolk $D$, Rosenwasser $R$, et al. AHA scientific statement: recommendations for the management of intracranial arteriovenous malformations: a statement for healthcare professionals from a special writing group of the Stroke Council, American Stroke Association. Stroke 2001; 32 1458-71.

25. Sisti MB, Kader A, Stein BM. Microsurgery for 67 intracranial arteriovenous malformations less than $3 \mathrm{~cm}$ in diameter. J Neurosurg 1993; 79: 653-60.

26. Spetzler RF, Martin NA. A proposed grading system for arteriovenous malformations. J Neurosurg 1986; 65: 476-83.

27. Hamilton MG, Spetzler RF. The prospective application of a grading system for arteriovenous malformations. Neurosurgery 1994; 34: 2-6.

28. Pikus HJ, Beach ML, Harbaugh RE. Microsurgical treatment of arteriovenous malformations: analysis and comparison with stereotactic radiosurgery. J Neurosurg 1998; 88: 641-6.

29. Heros RC, Morcos J, Korosue K. Arteriovenous malformations of the brain: surgical management. Clin Neurosurg 1993; 40: 139-73.

30. Maruyama K, Kawahara N, Shin M, Tago M, Kishimoto J, Kurita $\mathrm{H}$, et al. The risk of hemorrhage after radiosurgery for cerebral arteriovenous malformations. N Engl J Med 2005; 352: 146-53.
31. Friedman WA, Bova FJ, Mendenhall WM. Linear accelerator radiosurgery for arteriovenous malformations: the relationship of size to outcome. J Neurosurg 1995; 82: 180-9.

32. Fleetwood IG, Steinberg GK. Arteriovenous malformations. Lancet 2002; 359: 863-73.

33. Flickinger JC, Kondziolka D, Maitz AH, Lunsford LD. An analysis of the dose-response for arteriovenous malformation radiosurgery and other factors affecting obliteration. Radiother Oncol 2002; 63: 347-54.

34. Sirin S, Kondziolka D, Niranjan A, Flickinger JC, Maitz AH, Lunsford LD. Prospective staged volume radiosurgery for large arteriovenous malformations: indications and outcomes in otherwise untreatable patients. Neurosurgery 2006; 58: 17-27.

35. N-BCA Trial Investigators: N-butyl cyanoacrylate embolization of cerebral arteriovenous malformations: results of a prospective randomized multicenter trial. AJNR Am J Neuroradiol 2002; 23: 748-55.

36. Cockroft KM, Hwang SK, Rosenwasser RH. Endovascular treatment of cerebral arteriovenous malformations: indications, techniques, outcome, and complications. Neurosurg Clin N Am 2005; 16: 367-80.

37. Gobin YP, Laurent A, Merienne L, Schlienger M, Aymard A, Houdart E, et al. Treatment of brain arteriovenous malformations by embolization and radiosurgery. Neurosurg 2006; 59: 53-8.

38. Soderman M, Andersson T, Karlsson B, Wallace MC, Edner G. Management of patients with brain arteriovenous malformations. Eur J Radiol 2003; 46: 195-205.

39. Weber W, Kis B, Siekmann R, Kuehne D. Endovascular treatment of intracranial arteriovenous malformations with onyx: technical aspects. AJNR Am J Neuroradiol 2007; 28: 371-7.

40. Taylor CL, Dutton K, Rappard G, Pride GL, Replogle $\mathrm{R}$, Purdy $\mathrm{PD}$, et al. Complications of preoperative embolization of cerebral arteriovenous malformations. J Neurosurg 2004; 100: 810-2

41. Turjman F, Massoud TF, Vinuela F, Sayre JW, Guglielmi G, Duckwiler G. Correlation of the angioarchitectural features of cerebral arteriovenous malformations with clinical presentation of hemorrhage. Neurosurgery 1995; 37: 856-60.

42. Lasjaunias P, Piske R, Terbrugge K, Willinsky R. Cerebral arteriovenous malformations (C. AVM and associated arterial aneurysms (AA): analysis of $101 \mathrm{C}$. AVM cases, with 37 AA in 23 patients. Acta Neurochir (Wien 1988; 91: 29-36.

43. Redekop G, TerBrugge K, Montanera W, Willinsky R. Arterial aneurysms associated with cerebral arteriovenous malformations: classification, incidence, and risk of hemorrhage. J Neurosurg 1998; 89: 539-46.

\section{ENGLISH SUMMARY}

\section{Cerebral arteriovenous malformations - overview}

Ólafur Árni Sveinsson', Ingvar H. Ólafsson², Einar Már Valdimarsson ${ }^{3}$

Cerebral arteriovenous malformations (AVMs) are uncommon but can cause intracerebral hemorrhage with grave disability or death. AVMs can even cause focal neurological symptoms, seizures and headache. The treatment of AVMs is complex. The most common treatment forms are microsurgery, stereotactic radiotherapy and endovascular embolization. The best treatment in each case can include a combination of the mentioned treatment forms. New studies indicate that no intervention is the best option in unruptured AVMs. In this article we discuss the epidemiology, diagnosis and treatment of cerebral AVMs.

${ }^{1}$ Department of Neurology Karolinska Hospital, Stockholm, Sweden, ${ }^{2}$ Department of Neurosurgery, University Hospital of Iceland, ${ }^{3}$ Department of Neurology, University Hospital of Iceland, Reykjavík, Iceland.

Key words: cerebral arteriovenous malformations, intracerebral hemorrhage, seizures, headache, surgery, radiation, endovascular embolization.

Correspondence: Ólafur Sveinsson, olafur.sveinsson@karolinska.se 